\title{
An update on source-to-sink carbon partitioning in tomato
}

\author{
Sonia Osorio ${ }^{1,2}$ *, Yong-Ling Ruan ${ }^{3,4}$ and Alisdair R. Fernie ${ }^{2}$ \\ 1 Instituto de Hortofruticultura Subtropical y Mediterránea "La Mayora," Department of Molecular Biology and Biochemistry, University of Malaga - Consejo \\ Superior de Investigaciones Científicas, Málaga, Spain \\ ${ }_{2}^{2}$ Max-Planck-Institut für Molekulare Pflanzenphysiologie, Potsdam-Golm, Germany \\ ${ }^{3}$ Australia-China Research Centre for Crop Improvement, The University of Newcastle, Callaghan, NSW, Australia \\ ${ }^{4}$ School of Environmental and Life Sciences, The University of Newcastle, Callaghan, NSW, Australia
}

\section{Edited by:}

Leo Marcelis, Wageningen UR

Greenhouse Horticulture and Wageningen University Horticultural

Production Chains, Netherlands

\section{Reviewed by:}

Hartmut Stützel, Leibniz Universität

Hannover, Germany

Remi Lemoine, Université of

Poitiers-Centre National de la

Recherche Scientifique, France

Lucía Galiano Pérez, Swiss Federal

Institute for Forest, Snow and

Landscape Research, Switzerland

Nadia Bertin, Institut National de la

Recherche Agronomique, France

\section{${ }^{*}$ Correspondence:}

Sonia Osorio, Instituto de

Hortofruticultura Subtropical y

Mediterránea "La Mayora",

Department of Molecular Biology and Biochemistry, University of Malaga -

Consejo Superior de Investigaciones Científicas, Edificio I + D, 3ra Planta,

Campus de Teatinos, 29071 Málaga,

Spain

e-mail:sosorio@uma.es
Plant growth and carbon metabolism are closely associated since carbohydrate in the form of sucrose generated by photosynthesis, provides the primary source of building blocks and energy for the production and maintenance of biomass. Regulation of carbon partitioning between source and sink tissues is important because it has a vast influence on both plant growth and development. The regulation of carbon partitioning at the whole plant level is directly linked to the cellular pathways of assimilate transport and the metabolism and allocation of sugars, mainly sucrose and hexoses in source leaves, and sink organs such as roots and fruit. By using tomato plant as a model, this review documents and discusses our current understanding of source-sink interactions from molecular to physiological perspectives focusing on those that regulate the growth and development of both vegetative and reproductive organs. It furthermore discusses the impact that environmental conditions play in maintenance of this balance in an attempt to address the link between physiological and ecological aspects of growth.

\section{INTRODUCTION}

The partitioning and allocation of carbon (C) is intimately connected to plant growth since the export of carbohydrate from photosynthesizing leaves provides the substrate for the growth and maintenance of non-photosynthetic tissues. Through photosynthesis plants can highly efficiently convert $\mathrm{CO}_{2}$ into 3phosphoglyceric acid and glyceraldehyde-3-phosphate leading to the biosynthesis of sugars as well as terpenoids and fatty acids. This fixed carbon is transformed into reserve molecules, which can be broken down at a later time to provide the cell with ATP, reducing power, and carbon skeletons, which support a number of physiological functions including growth. Carbohydrates such as sucrose provide both an energy source and the building blocks for the production and maintenance of biomass.

Biomass accumulation in plants is a remarkably stable function of light intercepted by the canopy and $\mathrm{CO}_{2}$ transformation into dry matter via photosynthesis, thus illustrating the dependence of plant growth on $\mathrm{C}$ fixation. Photosynthetically active "source" tissues such as mature leaves, export fixed C, primarily in the form of sucrose, to non-photosynthetic "sink" tissues such as fruits or reproductive organs, tubers, meristems, or roots (Koch, 2004). During its life cycle, a typical plant undergoes considerable changes in the dynamics of carbon transport and metabolism in both source and sink organs as well as in the degree of competition among various sinks for the common pool of carbohydrates available. Changes in source and sink activities are known to induce cyclic patterns of growth (production flushes; Gary et al., 1993; Valentin et al., 1998; Gautier et al., 2001; Bertin et al., 2003). Commercial horticultural crops such as citrus and apple are exposed to a sustained pruning throughout their growth cycles in order to control their growth and to maintain a desired balance of photoassimilate partitioning between source and sink organs. However, altered source sink dynamics across development are by no means confined to crop species with several reports evidencing this behavior in non-cultivated species (Graf et al., 2010; Pyl et al., 2012; Sulpice et al., 2014).

In order to fully understand the relationship between photoassimilate partitioning and growth, we need to consider three important key steps, (1) production of photoassimilates (source capacity), (2) transport of photoassimilates, and (3) utilization of photoassimilates in sink organs (Figure 1). This brief review highlights the role of carbohydrate transport and metabolism in plant growth and its perspective in altering agronomic yield. For this purpose we focus on recent development in tomato, which as well as being an important horticultural crop is a model for research on source-sink interactions and competition. 


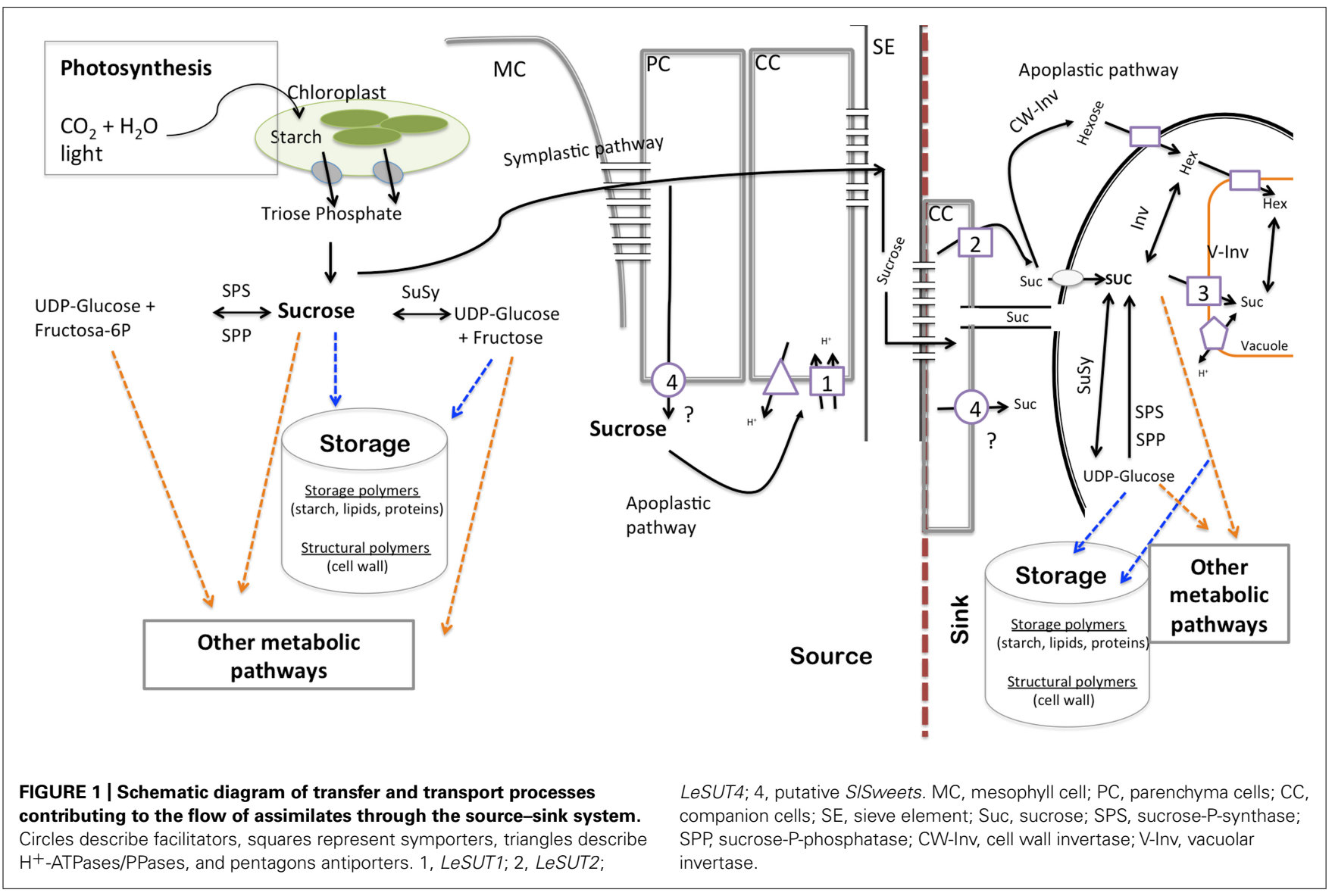

\section{CARBOHYDRATE PARTITIONING IN SOURCE TISSUES}

The photosynthetic activity of source tissues is determined by the activity of various enzymes of the Calvin-Benson cycle, which can be divided into three distinct phases. In phase 1 (carbon fixation), $\mathrm{CO}_{2}$ is condensed with the five-carbon sugar ribulose bisphosphate. This reaction is catalyzed by ribulose 1,5bisphosphate carboxylase (Rubisco) generating two molecules of 3-phosphoglycerate (3-PGA). In phase 2 (reduction), the 3-PGA is converted to glyceraldehyde 3-phosphate, the threecarbon precursor of sucrose. In phase 3 (regeneration), the ribulose bisphosphate is regenerated in order to incorporate $\mathrm{CO}_{2}$ to initiate the cycle. In order to remobilize the inorganic phosphate incorporated in the primary products of photosynthesis, assimilates are converted either to sucrose in the cytosol, or to transitory starch, which is synthesized in the plastids and degraded into glucose and maltose at night. Starch can be seen as an overflow product synthetized when the rate of $\mathrm{CO}_{2}$ fixation exceeds the rate of sucrose synthesis. Feedback inhibition of sucrose synthesis via the signal metabolite fructose2,6-bisphosphate leads to the accumulation of phosphorylated intermediates and decrease inorganic phosphate $(\mathrm{Pi})$ in the chloroplast, resulting in activation of ADP-glucose pyrophosphorylase (AGPase) by a rising glycerate-3-phosphate:Pi ratio (MacRae and Lunn, 2006). Recent study on a series of TILLING mutants with smaller changes in AGPase activity demonstrated that AGPase exerts control over the pathway of starch synthesis (Hädrich et al., 2011). Moreover, the sugar trehalose-6-phosphate (Tre6P) has been proposed to act as an intermediate between sucrose and AGPase (Kolbe et al., 2005), which might provide the route whereby starch accumulation is linked to the sucrose and, possibly, plant carbon status (Smeekens etal., 2010; Stitt etal., 2010).

An important question concerning the capacity of a source leaf is whether the photosynthetic activity is always running at its maximum or is rather controlled by the metabolism of photoassimilates within, or their transport to, sink tissues. There are several examples of sink-dependent alteration of photosynthesis of source leaves. The overexpression of a sucrose phosphate synthase (SPS) gene in tomato caused considerable modification of carbon allocation within the leaves and additionally at the whole plant level. Most importantly, the amount of sucrose unloaded into the fruit was considerably higher, which lead to increase the total fruit number as well as total fruit weight (Micallef et al., 1995). Thus, suggesting that not only development, but also fruit growth are limited by sucrose available from phloem unloading. Consistently with this hypothesis, transgenic tomatoes with reduced sucrose synthase (SuSy) activity that catalyzes the cleavage of sucrose into UDP-glucose and fructose, displayed a reduced sucrose unloading capacity, leading to reduced fruit set as well as slower growth rate (D'Aoust et al., 1999). The negative effect of suppression of SuSy on fruit set is reminiscent of that on seed development observed in SuSy deficient maize (Chourey et al., 1998) and cotton (Ruan 
et al., 2008). Similarly, tomato plants constitutively overexpressing the hexokinase 1 gene of Arabidopsis displayed reduced photosynthetic rates as well as harboring smaller fruit containing lower sugar content (Dai et al., 1999; Menu et al., 2004).

Tomato fruits initially contain chloroplasts that are photosynthetically active, but these differentiate to non-photosynthetic chromoplasts during ripening. This transition would appear to be coupled to a decline in the expression of genes (Alba etal., 2004; Carrari etal., 2006; Kahlau and Bock, 2008; Osorio et al., 2011) and enzyme activities (Schaffer and Petreikov, 1997; Steinhauser et al., 2010) associated with carbon assimilation. Despite the high expression of photosynthetic genes (LemaireChamley etal., 2005), fruit are rarely net assimilators of $\mathrm{CO}_{2}$ (Carrara et al., 2001). Moreover, the triose phosphate and glucosephosphate transporters are both active in tomato chloroplasts, indicating that both could import and export phosphoesters. Early studies shown that tomato fruit contributes by its own fixed carbon between 10 and 15\% of the carbon skeletons required (Tanaka et al., 1974). A similar effect was also observed in transgenic tomato with reduced chloroplastic fructose-1,6-biphosphatase activity and thus likely reduced rates of fruit photosynthesis (Obiadalla-Ali et al., 2004). Moreover, the combined metabolomic and transcriptomic analyses of tomato plants with reduced expression of $A u x / I A A$ transcription factor IAA9, suggested an important role for photosynthesis of ovary in the initiation of fruit development (Wang et al., 2009). A recent study showed that fruit-specific reduction in the expression of glutamate 1-semialdehyde aminotransferase (GSA), which has previously been documented to contribute to the control of chlorophyll biosynthesis (Höfgen et al., 1994), displayed lower chlorophyll levels and photosynthetic activity but few other differences. Indeed, no differences in fruit size, weight, or ripening capacity and only minor alterations in other primary or intermediary metabolites were observed (Lytovchenko et al., 2011). These results, suggest that fruit photosynthesis is not essential for fruit energy metabolism. However, the same study intriguingly demonstrated that fruit photosynthesis was important for seed set, indicating that further study is required to enhance our understanding of the interactions between different organs of the plant. Two recent studies provide highly intriguing insights into the competition for assimilates within the plant (Génard et al., 2010; Toubiana et al., 2012). The work of Toubiana et al. (2012), follows on from earlier work on tomato introgression lines which revealed clear negative correlations between fruit amino acid levels and the harvest index (the proportion of dry weight of the plant invested in, in this instance, its fruits; Schauer et al., 2006) even used pruning to simulate agronomic practice (Do et al., 2010). The latter study likely provides information with regard to environmental manipulations, which alter source-tosink partitioning. That said much broader analysis such as those carried out in a collection of Arabidopsis accessions grown under a variety of $\mathrm{C}$ and $\mathrm{N}$ availabilities (Kleessen et al., 2012; Sulpice et al., 2013), will be required in order to achieve greater insight into the interplay between plant, environment, metabolism, and growth.

\section{TRANSPORT OF CARBOHYDRATES FROM SOURCE-TO-SINK}

All photoassimilates that are not required for the support of leaf function are converted into sucrose or amino acids and loaded into the phloem for translocation to the sink organs. High concentration of sucrose in the sieve elements (SEs) of source tissues raise turgor pressure, resulting in hydrostatic pressuredriven mass flow of sugars to the SEs of sink tissues, where sugars are unloaded and turgor pressure drops. Sugar transport is highly regulated (Tiessen and Padilla-Chacon, 2013), and sucrose-specific signaling is involved in controlling transport activity (Chiou and Bush, 1998). Different transporters are required for efficient movement of sucrose across plasma membranes for apoplastic phloem loading in tomato source leaves and phloem unloading in fruit pericarp at the rapid expansion phase (Ruan and Patrick, 1995). These operate with different energetic and kinetic constraints rendering them suitable for: (i) efficient export into cell wall spaces, a process most likely mediated by sucrose facilitators such as AtSWEET11 and 12 (Chen et al., 2012), (ii) uptake of sucrose in cells as mediated by Suc/ $\mathrm{H}^{+}$symporters (Carpaneto et al., 2005), (iii) loading from the cytosol into storage vacuoles by hexose $/ \mathrm{Suc} / \mathrm{H}^{+}$antiporters (Milner etal., 1995; Brown etal., 1997; Ruan et al., 1997), and (iv) fine-tuning of sucrose/hex flux in order to on the one hand maintain homoeostasis and on the other regulate intraorganellar signaling.

In tomato, three sucrose transporter genes have been identified, LeSUT1, LeSUT2, and LeSUT4. All three proteins were demonstrated to be co-localized in the SEs, whereas transcription of SUT1 was also shown to take place in companion cells (Barker et al., 2000; Weise et al., 2000). LeSUT1 is mainly expressed in sucrose exporting source leaves; whereas LeSUT2 is expressed predominantly in sink organs such as sink leaves, stem, and fruits (Barker et al., 2000). Although the expression patterns of LeSUT1 and LeSUT2 are different at the tissue level, they are co-localized in the SEs in the loading and transport zone, particularly in leaves, petioles, and stem tissues. Moreover, both genes have been proven to physically interact, which is suggestive of the potential formation of oligomeric complexes with unique transport capacities (Reinders et al., 2002). However, oligomerization of the sucrose transporters has yet to be confirmed in planta, so the physiological importance of this observation is currently unknown. If sucrose transport mediated by these transporters is essential for phloem loading, then a reduction in transport activity would be anticipated to lead to feedback inhibition of photosynthesis and a consequent reduction in the supply of carbon to the sink organs. In order to test this hypothesis, transgenic tomato plants were generated which independently suppressed the expression of LeSUT1 and LeSUT2. The leaves of LeSUT1 antisense plants displayed early senescence and chlorosis. Furthermore, the rate of photosynthesis in these plants was reduced and analysis of metabolites revealed an accumulation of soluble sugars and the inability to mobilize transitory starch during prolonged dark treatment. Moreover, measurements of $\mathrm{C}$ efflux from cut petioles indicated a blockage in phloem loading a fact that rendered the plants unable to produce normal fruits (Hackel et al., 2006). By contrast reduced LeSUT2 expression exclusively affected tomato fruit seed development, pollen germination, and pollen tube length. The data suggest, that LeSUT1 and LeSUT2 appear to have a role in phloem loading and unloading, respectively (Hackel et al., 2006). 
The sucrose transporter of group 4 (LeSUT4) was originally published as high capacity transporter of phloem minor veins (Weise et al., 2000). However, the recent finding of other sucrose transporters from group 4 in Arabidopsis and barley tonoplasts (Endler et al., 2006), raises questions about the initial interpretation with it seeming more likely that group 4-type transporters are vacuolar sucrose transporters that are primarily expressed in sink tissues.

Recently, a new class of sugar transporters called SWEETs, which are involved in the release of sugars to the apoplast, have been described in Arabidopsis and rice (AtSWEET 10-15; OsSWEET 11 and 14; Chen et al., 2012). The Arabidopsis double mutant, atsweet 1;12, displayed reduced export of carbon from the leaf, increased accumulation of starch, and a reduced photosynthetic capacity (Chen et al., 2012). The SWEET proteins have not yet been identified in tomato but can be predicted that they operate at the placenta-seed interface, in outer pericarp, at early developmental stages during hexose accumulation phase (Ruan and Patrick, 1995; Jin et al., 2009). Here, the Suc effluxers likely facilitate the sucrose export into the apoplasm where Suc is hydrolysed by invertases into glucose and fructose prior to uptake by $\mathrm{Hex} / \mathrm{H}^{+}$ symporters (Ruan et al., 2010). However, direct molecular genetic testing of this hypothesis is yet to be performed.

The importance of the supply to and the subsequent mobilization of sucrose in, heterotrophic organs has been the subject of considerable research effort spanning many years (Miller and Chourey, 1992; Zrenner etal., 1996; Heyer et al., 2004; Lytovchenko etal., 2007). While the mechanisms of sucrose loading into the phloem has been intensively studied over a similar time period (Riesmeier et al., 1993, 1994; Bürkle et al., 1998; Meyer etal., 2004; Sauer et al., 2004), those by which it is unloaded into the sink organ have only been clarified relatively recently (Bret-Harte and Silk, 1994; Viola et al., 2001; Kuhn et al., 2003; Carpaneto et al., 2005). In tomato, early studies suggested that sucrose unloading in pericarp during early stages of fruit development is likely symplasmic (Ruan and Patrick, 1995; Damon et al., 1998; D'Aoust et al., 1999). The post-phloem cellular pathway in the outer fruit pericarp was shown to shift from symplastic during starch accumulation (13-14 days after anthesis) to apoplastic during hexose accumulation (23-25 days after anthesis; Offler and Horder, 1992; Ruan and Patrick, 1995; Patrick and Offler, 1996). During the switch from the starchaccumulating to the sugar-accumulating phase, the symplastic continuity between phloem and storage parenchyma is diminished and an apoplastic unloading step for sucrose was thought to predominate. This symplastic-to-apoplastic switch is consistent with facilitated transport to accumulate soluble sugars at high concentrations without attenuating phloem unloading due to osmotic effect exerted from the recipient sink cells (Offler and Horder, 1992). Three sugar transporter genes (acc. numbers: U321367, U336512, U318421) were found to co-localize with quantitative trait locus (QTLs) for sugar accumulation in tomato fruit (Prudent et al., 2011). Moreover, cultivar differences in hexose content of tomato fruit correlate well with maximal activities of hexose $/ \mathrm{H}^{+}$symporters (Ruan et al., 1997). This relationship was verified by RNAi knockdown of three hexose symporters (McCurdy et al., 2010) which localize to plasma membrane of storage parenchyma cells (Dibley etal., 2005). The reduction in fruit expression levels of these three hexose symporters caused a decrease in fruit hexose accumulation. By contrast, photoassimilate production by source leaves and phloem transport capacity to fruit were unaffected (McCurdy et al., 2010).

\section{CARBOHYDRATE METABOLISM AND ACCUMULATION IN SINK TISSUES}

Experimental manipulations of source supply, source activity, and sink strength have all provided strong evidence for the hypothesis that photosynthesis and sink utilization of carbohydrates are tightly coordinated (Paul and Foyer, 2001; Kaschuk et al., 2010). Generally, when sink activity is decreased by removing active sinks or introducing nutrient deficiency, carbohydrates accumulate in leaves and photosynthesis becomes inhibited (Paul and Pellny, 2003), which does not depend on the sink removal, but on the remaining sink capacity. Similarly, when sucrose export from source leaves is restricted, photosynthesis is inhibited (Krapp and Stitt, 1995; Bürkle et al., 1998; Zhang and Turgeon, 2009), which is due to the remaining transport capacity. Therefore, the amount of sugars accumulated in fruit is not only dependent on endogenous metabolic processes but also in the degree of phloem unloading, since tomato fruits have a low photosynthetic activity (Farrar and Williams, 1991) which is actually not even required to support fruit growth (Lytovchenko et al., 2011).

As mentioned above some studies postulate apoplastic unloading from phloem throughout tomato fruit development (Zanor et al., 2009), especially during phases of hexose accumulation (Ruan and Patrick, 1995). In such a scenario, cell wall invertase catalyzes the breakdown of sucrose into glucose and fructose in the apoplasm, which have the potential to regulate sugar fluxes by increasing apoplasmic levels of hexoses. The apoplasmic unloading of sugar can thus facilitate influx of hexoses across plasma membrane of storage cells or can accelerate the efflux of sucrose from phloem to sink apoplasm by sucrose concentration differences, possibly mediated by SWEET sucrose effluxers, as recently reported in Arabidospis and rice (Chen et al., 2012). The Solanum pennellii apoplasmic invertase (LIN5) identified as QTL for hexose accumulation in the tomato introgression line (Brix9-2-5), was characterized by a higher affinity for sucrose. Thus tomato containing the S. pennellii LIN5 exhibited a significant increase in soluble solids (usually sugars and acids) without a negative impact on fruit yield (Fridman et al., 2002, 2004; Gur and Zamir, 2004; Zanor et al., 2009). Increasing the activity, by silencing its inhibitor (INVINH1), similarly increased fruit sugar level and seed size (Jin et al., 2009). The metabolic rationale behind the strategy of apoplasmic invertase modification is that the hydrolysis of translocated sucrose at the point of unloading in the fruit sink can increase the gradient of translocation from source-to-sink and hence the net import into the fruit (Ho, 1996; Fridman et al., 2004; Koch, 2004). In addition, such a strategy has the added advantage that it generates glucose signals, which stimulate cell growth and sugar accumulation (Jin et al., 2009). By contrast to the effects from developmental regulation of cell wall invertase activity, constitutive knockdown of a vacuolar soluble acid invertase SAI (TIV1) 
caused a switch from hexose-accumulation to sucrose-storing tomato fruit without any change in total sugar content per fruit (Klann etal., 1996). Sucrose-accumulating fruits were smaller than control fruits, which suggest that soluble acid invertase controls sugar composition and cell expansion, consistent with the function of SAI in other plant systems (Roitsch and Gonzalez, 2004).

AGPase is a key regulatory plastidial enzyme of starch biosynthesis and maps to a QTL for sugar content (Petreikov et al., 2009). A tomato introgression line of $S$. habrochaites was characterized by increasing sugar content and higher AGPase activity that resulted from temporally extended expression of AGPase large subunit (Petreikov et al., 2006). These tomatoes exhibited higher starch content in the immature fruit, which leaded to higher total soluble solids (mainly sugar) and fruit size at mature stage (Petreikov et al., 2006). The relationship between AGPase activity and tomato sugar content has been verified altering malate metabolism, which post-translationally affects AGPase activity through an effect on cellular redox balance (Centeno et al., 2011; Osorio et al., 2013). Moreover, while modification in malate metabolism in tomato fruit had relatively little effect on the total fruit yield, they had dramatic consequences in postharvest shelf life and susceptibility to bacterial infection, which is an important consequence of altered C partitioning (Centeno et al., 2011).

Nowadays, there is an important debate whether or not C storage should be considered as an actively regulated sink instead of being a simple surplus resulted when supply of new assimilated carbon is higher than demands. To date, our understanding of the regulation of storage is based on diurnal starch dynamics, where starch is accumulated during the day to support growth and respiration at night. Therefore, from these studies can be concluded that the synthesis and degradation of starch are controlled by independent regulatory networks that allow plants to balance carbon supply via photosynthesis with $\mathrm{C}$ use for growth and other activities (Sulpice et al., 2009; Stitt and Zeeman, 2012). Although this question has not been opened in tomato plants, in long-lived trees recent attempts at explaining $\mathrm{C}$ limitation under stress suggest that priority allocation to storage could compete with growth and make assimilated C a limiting resource (McDowell, 2011; Sala et al., 2012). This considerations imply that under limiting availability of assimilates, $\mathrm{C}$ storage is given priority over growth, because ultimately survival depends more on $\mathrm{C}$ demands for metabolism than for growth (Sala et al., 2012). However, further empirical evidences are needed to corroborate these theories.

\section{SOURCE-SINK REGULATION BY STRESS}

Plants are able to perceive and respond to a wide range of biotic and abiotic stimuli (Metlen et al., 2009). In response to these stimuli they undergo physiological, biochemical, and physical changes to produce a phenotype that match their environment (Sultan, 2000). Such phenotypic plasticity can be expressed locally at the site affected by stimuli. However, plants can also coordinate their responses to changes in their surroundings with other plant modules and respond in a systemic and integrated manner at the whole-plant level (de Kroon et al., 2005).

Upon attack by herbivores, plants produce a number of defensive compounds and structures that hinder the performance and fitness of the attackers. Several studies have shown that herbivore attack leads to reallocation of carbon and nitrogen from damaged leaves into storage tissues (Babst et al., 2005, 2008; Schwachtje et al., 2006), often in a rapid manner known as induced sequestration (Orians et al., 2011). In tomato specifically, export of nitrogen from leaves into roots has been shown in response to methyljasmonate (Gómez et al., 2010). Recently, the whole-plant metabolic responses of tomato after leaf herbivory by two caterpillars (the generalist Helicoverpa zea and the specialist Manduca sexta) were characterized using metabolic analysis (Steinbrenner et al., 2011). In this study, it was found that the primary metabolic responses across the entire tomato plant varied widely from tissue to tissue. The induced metabolic change was stronger in the apex and root tissues than in undamaged leaflets of damaged leaves, indicating rapid and significant whole-plant responses to damage. Interestingly, these metabolic changes were herbivore-specific, which $H$. zea herbivory strongly affected concentrations of defense-related metabolites, while $M$. sexta altered metabolites associated with carbon and nitrogen transport (Steinbrenner et al., 2011; Gómez et al., 2012).

Stresses including insufficient supply of nutrients, drought, heat, or cold, often induce seed and fruit abortion and, hence, irreversible yield losses (Boyer and McLaughlin, 2007; Bita et al., 2011; Li et al., 2012; Ruan et al., 2012). For example, heat stress can result in $70 \%$ yield loss in tomato as a result of flower and fruit abortion (Bita et al., 2011). If several enough, heat stress can also led to $100 \%$, or to $10 \%$ if it is only mild (Sato et al., 2000). Therefore, any exogenous factors, which alter the resource availability from source and its utilization within sink, can be anticipated to influence carbohydrate partitioning, and sink yield and quality.

Heat mainly affects the biochemical reactions of photosynthesis, and depending on the duration and intensity, can irreversible damage Rubisco, oxygen-evolving complexes, chloroplast ultrastructure, thylakoid membranes, and PSII reaction centers (Havaux, 1993; Camejo et al., 2005, 2006). Tomato has an optimum growth temperature of $24-26^{\circ} \mathrm{C}$ in the day and $18-20^{\circ} \mathrm{C}$ at night. Temperatures above $30^{\circ} \mathrm{C}$ in the daytime and $21^{\circ} \mathrm{C}$ at night as well as lower that $15^{\circ} \mathrm{C}$ could block the reproductive (gametophytic) phase in flowering plants, resulting in low pollen viability, poor pollen elongation, and ultimately fruit abortion (Weaver and Timm, 1989). A recent study has revealed that the reproductive development of tomato is more sensitive to high night temperature than day temperature (Liu et al., 2012). This implies that lack of photoassimilate supply at night aggravates heat-induced damage. A pollination of heat-stressed and emasculated flower with non-stressed pollen reduce the flower abortion rate, which indicate that pollen development is more vulnerable to heat stress than the female organs in tomato (Ruan et al., 2010). The reduction of tomato pollen viability by heat could be attributed to reduction in starch accumulation in developing pollen grains and total soluble sugar in the anther wall (Pressman et al., 2002). Further analysis by the same group revealed that reduction of cell wall invertase activity in anthers might be the major factor contributing to pollen sterility under heat stress (Pressman et al., 2006). This reduction in the cell wall invertase activity could be due to an induction of the invertase inhibitor protein (Frank et al., 
2009). Interestingly, expression of SPS was also up-regulated by heat in maturing tomato pollen (Frank et al., 2009). SPS is a key enzyme in the biosynthesis of sucrose, which is thought to play an important role as osmo-protectant in the maintenance of cell membrane integrity and thereby cellular function. Recently, $\mathrm{Li}$ et al. (2012) described the influence of heat stress on fruit and seed set, a critical phase for realizing yield potential. They examined patterns of carbon allocation and sucrose cleavage enzymes in heat-tolerant and -sensitive tomato lines finding a strong correlation between high invertase activity and increased sucrose import into young fruit, and heat-tolerance most likely due to an increase in sink strength and sugar signaling activities (Li et al., 2012).

Drought induces large alterations in source-sink relations due to a modification of growth priorities and to a reduction of the performance of photosynthetic organs (Vu et al., 1999). For instance, water stress could inhibit fruit growth as a result of both sink and source limitations (Chaves et al., 2009; Muller et al., 2011). Similarly to the response of plants to heat and cold stresses, the reproductive phase in flowering plants is often highly sensitive to drought stress (Guilioni et al., 1997; Smith and Stitt, 2007). Some studies have addressed the regulation of source- and sink-specific enzymes in response to water deficit. In this vein, several studies demonstrated that the reduced expression of cell wall and vacuolar invertases in drought stress could promote abortion (Andersen et al., 2002; McLaughlin and Boyer, 2004; Zanor et al., 2009). However, it is important to note that these studies were merely correlative and that changes in hormone levels (Andersen et al., 2002) and in the expression of a diverse range of other genes (Boyer and McLaughlin, 2007) have also been reported to occur coincidently to abortion. Tomato transformants deficient in the expression of the cell wall invertase gene, LIN5, showed a higher incidence of abortion (Zanor et al., 2009). This suggest that the reduction in apoplasmic invertase activity is likely an early step in the signal transduction cascade linking perception of stress to the initiation of senescence and membrane degradation events that lead to irreversible abortion (Zanor et al., 2009). The changes documented in these transformants in the expression of genes associated with hormonal synthesis and function, provide hints to the nature of this cascade which may ultimately lead to its elucidation. It was recently shown that the reduced activity of another apoplastic enzyme, ascorbate oxidase, correlated with increased final fruit yield under drought stress (Garchery et al., 2013). This manipulation resulted in increases in stomatal conductance in leaf and sugar content, as well as a modified apoplastic hexose:sucrose ratio with the authors arguing that the increased redox state of the apoplast protects against the rise in reactive oxygen species (ROS) levels following stress. Therefore, ascorbate oxidase may be a good candidate for strategies aimed at improving water stress tolerance in tomato.

The detrimental effects of salts result not only from a water deficit due to the relatively high solute concentrations in the soil but also from specific $\mathrm{Cl}^{-}$and $\mathrm{Na}^{+}$stresses. The physiology of the tomato in salty and non-salty conditions has been extensively studied, revealing an inhibition in growth and development, respiration, and protein synthesis as well as disruption in nucleic acid metabolism and an increase in oxidative stress (Zhang and
Blumwald, 2001; Jiménez et al., 2002; Gautier et al., 2009; Manaa et al., 2011, 2013). Additionally, in salt-treated plants, stomatal closure caused by depletion of cellular water content and the reduction in the transport of assimilates are the main causes of photosynthesis inhibition (Hare et al., 1998). Moreover, accumulation of glucose, fructose, and mainly sucrose in leaves as well as in ripe tomato fruits can also lead to a decrease in photosynthesis by feedback inhibition mechanisms (Poljakoff-Mayber and Lerner, 1994; Gautier et al., 2010). Furthermore, salinity leads to osmotic stress due to depletion of cellular water (Hare et al., 1998). This osmotic adjustment could lead to an accumulation in the vacuole of compatible solutes and ions, thus increasing the turgor potential (Romero-Aranda et al., 2001). However, an increase in the turgor pressure is not always related with an increase in water content in the cell, as cell size has also been documented to be reduced under conditions of salinity. Romero-Aranda et al. (2001) observed that it reduced cell expansion in tomato plants, where it was associated with a reduced osmotic and water potential and an increase in the turgor potential. Several cellular processes involved in salt-stress tolerance including osmotic adjustment, osmo-protection, ion homeostasis, elimination of oxygen scavengers, stress response are linked with the duration of the stress (Munns etal., 2002). Intriguingly, application of exogenous calcium has a mitigating effect on tomato fruit by salinity where it seems to induce adaptation via the activation of the enzymes involved in energy and carbohydrate metabolism (Gautier et al., 2009; Manaa et al., 2013). However, considerable further research is required in order to define the mechanisms by which calcium mediates this impact on metabolism and growth.

Plants grown for long periods at elevated $\left[\mathrm{CO}_{2}\right]$ show a down regulation of leaf photosynthesis (Delucia et al., 1985; Sage et al., 1989), and carbohydrate source-sink balance is believed to have a major role in the regulation of photosynthesis through feedback inhibition (Stitt, 1991). Source-sink imbalance may occur during exposure to elevated $\left[\mathrm{CO}_{2}\right]$ when photosynthesis rate exceeds the export capacity or the capacity of sinks to use photosynthates for growth, resulting in an accumulation of carbohydrates in photosynthetically active source leaves (Stitt, 1991). As we have previously mentioned, levels of soluble sugars in plant cells have been shown to influence the regulation of expression of several genes coding for key photosynthetic enzymes (Koch, 1996; Pego et al., 2000). The buildup in carbohydrates may signal the repression, but does not directly inhibit the expression, of Rubisco and other proteins that are required for photosynthesis (Stitt, 1991; Jang and Sheen, 1994; Makino and Mae, 1999). In tomato, transcript levels for Rubisco subunits, chlorophyll $a / b$ binding protein $(\mathrm{Cab})$, and Rubisco activase ( $R c a)$ decline with $\mathrm{CO}_{2}$ enrichment, whereas those for core proteins in phosystems I and II remain unchanged (Van Oosten et al., 1994; Van Oosten and Besford, 1995). Also, despite a large accumulation of starch occurring in leaves of elevated $\mathrm{CO}_{2}$ grown plants, transcript levels for AGPase show little change (Van Oosten et al., 1994). Furthermore, although photorespiration decreases under elevated $\left[\mathrm{CO}_{2}\right]$ (Stitt, 1991) responses of enzymes and/or transcripts associated with the photorespiratory pathway have not been well investigated (Moore et al., 1999). 
The response of plant growth to phosphorus $(\mathrm{P})$ limitation is shaped differently from the response to nitrogen $(\mathrm{N})$ limitation (Burns et al., 1997; De Groot et al., 2001). An explanation for this different response may be due to different function of $\mathrm{N}$ and $\mathrm{P}$ in the cell. $\mathrm{N}$ is part of the machinery of the plant's energy metabolism (photosynthesis and respiration), whereas a relatively large part of inorganic phosphate is incorporated in structural compounds (phospholipids, nucleic acids; Mengel and Kirkby, 1987). N limitation affects $\mathrm{CO}_{2}$ fixation directly through effects on photosynthetic components rich in nitrogen such as chlorophyll, light-harvesting complex, and Rubisco (Hikosaka, 1996; Evans and Poorter, 2001). Furthermore, N limitation may affect $\mathrm{CO}_{2}$ fixation indirectly due to the limitation of growth and the subsequent accumulation of carbohydrates and feedback limitation of photosynthesis (Paul and Driscoll, 1997; De Groot et al., 2001). P limitation as well as $\mathrm{N}$ limitation, affects photosynthesis but though different mechanisms (De Groot et al., 2003; Fujita et al., 2003). This P limitation may affects photosynthesis through changes in the activity of Calvin-cycle enzymes, RuBP regeneration and/or Rubisco activity as long as $\mathrm{P}$ plays an important regulatory role in starch and sucrose biosynthesis, Rubisco activation and is also part of ATP and NADPH/NADP ${ }^{+}$. To test these hypotheses, an elegant experiment was designed using tomato grown plants at low $\mathrm{N}$, high $\mathrm{N}$, low $\mathrm{P}$, and high $\mathrm{P}$ at two irradiances (De Groot et al., 2003). The results were consistent with the hypothesis of $\mathrm{N}$-limited produces an reduction of photosynthesis, possible by feedback from the leaf carbohydrate pool, while under P-limited conditions the production of assimilates is limited (De Groot et al., 2003). This evidence was strengthened by analysis of tomato plants grown in liquid culture under P starvation (Fujita et al., 2003). However, direct molecular evidence and information about the regulatory networks under $\mathrm{N}$ and $\mathrm{P}$ limitation remain to be defined.

\section{CONCLUSION AND PERSPECTIVES}

Growth and development in plants are integrated processes in which primary assimilation in source tissues is balanced by the metabolic needs of heterotrophic sinks. In this review, we briefly provide evidence that assimilate partitioning plays a central role in balancing photosynthetic activity in the leaves with photoassimilate utilization and storage in sink. The data presented clearly demonstrate that molecular tools can be applied to study whole plant physiology in the context of carbon partitioning and yield manipulation. However, to elucidate the mechanisms that regulate source-sink relations, complementary experimental approaches are required which also take environmental and eco(physio)logical factors into account. It will also be crucial to improve our understanding of plant sugar metabolism and unravel the underlying network of highly flexible regulatory mechanisms, which underpin it in order to gain insight into source-sink regulation. In a future world of elevated atmospheric carbon dioxide concentration and environmental deterioration, enhancing the capacity for sucrose export and carbon utilization is an important component of maximizing or even merely maintaining photosynthesis and yield. That said the concepts outlined here do not merely reflect the challenges presented in understanding the interplay between plant and environment, and metabolism and growth in a crop species such as tomato but have broader implications for understanding these trade-offs in any plant species.

\section{ACKNOWLEDGMENTS}

This work was supported in part by grants from the Max Planck Gesellschaft (to Sonia Osorio and Alisdair R. Fernie), by Ministerio de Ciencia e Innovación, Spain (Ramón and Cajal contract; Sonia Osorio) and by Ministerio de Economía y Competitividad, Spain (grant no. AGL2012-40066; Sonia Osorio and by Australina Research Council (ARC DP110104931 and DP120104148 to Yong-Ling Ruan).

\section{REFERENCES}

Alba, R., Fei, Z. L., Payton, P., Liu, Y., Moore, S. L., Debbie, P., et al. (2004). ESTs, cDNA microarrays, and gene expression profiling: tools for dissecting plant physiology and development. Plant J. 39, 697-714. doi: 10.1111/j.1365313X.2004.02178.x

Andersen, M. N., Asch, F., Wu, Y., Jensen, C. R., Naested, H., Mogensen, V. O., et al. (2002). Soluble invertase expression is an early target of drought stress during the critical, abortion-sensitive phase of young ovary development in maize. Plant Physiol. 130, 591-604. doi: 10.1104/pp.005637

Babst, B. A., Ferrieri, R. A., Gray, D. W., Lerdau, M., Schlyer, D. J., Schueller, M., et al. (2005). Jasmonic acid induces rapid changes in carbon transport and partitioning in Populus. New Phytol. 167, 63-72. doi: 10.1111/j.1469-8137.2005.01388.x

Babst, B. A., Ferrieri, R. A., Thorpe, M. R., and Orians, C. M. (2008). Lymantria dispar herbivory induces rapid changes in carbon transport and partitioning in Populus nigra. Entomol. Exp. Appl. 128, 117-125. doi: 10.1111/j.15707458.2008.00698.x

Barker, L., Kuhn, C., Weise, A., Schulz, A., Gebhardt, C., Hirner, B., et al. (2000). SUT2, a putative sucrose sensor in sieve elements. Plant Cell 12, 1153-1164. doi: 10.1105/tpc.12.7.1153

Bertin, N., Borel, C., Brunel, B., Cheniclet, C., and Causse, M. (2003). Do genetic make-up and growth manipulation affect tomato fruit size by cell number, or cell size and DNA endoreduplication? Ann. Bot. 92, 415-424. doi: $10.1093 / \mathrm{aob} / \mathrm{mcg} 146$

Bita, C. E., Zenoni, S., Vriezen, W. H., Mariani, C., Pezzotti, M., and Gerats, T. (2011). Temperature stress differentially modulates transcription in meiotic anthers of heat-tolerant and heat-sensitive tomato plants. BMC Genomics 12:384. doi: 10.1186/1471-2164-12-384

Boyer, J. S., and McLaughlin, J. E. (2007). Functional reversion to identify controlling genes in multigenic responses: analysis of floral abortion. J. Exp. Bot. 58, 267-277. doi: 10.1093/jxb/erl177

Bret-Harte, M. S., and Silk, W. K. (1994). Nonvascular, symplasmic diffusion of sucrose cannot satisfy the carbon demands of growth in the primary root tip of Zea mays L. Plant Physiol. 105, 19-33.

Brown, M. M., Hall, J. L., and Ho, L. C. (1997). Sugar uptake by protoplast isolated from tomato fruit tissues during various stages of fruit growth. Physiol. Plant. 101, 533-539. doi: 10.1111/j.1399-3054.1997.tb01034.x

Bürkle, L., Hibberd, J. M., Quick, W. P., Kuhn, C., Hirner, B., and Frommer, W. B. (1998). The $\mathrm{H}^{+}$-sucrose cotransporter NtSUT1 is essential for sugar export from tobacco leaves. Plant Physiol. 118, 59-68. doi: 10.1104/pp.118.1.59

Burns, I. G., Walker, R. L., and Moorby, J. (1997). "How do nutrients drive growth?" in Plant Nutrition-for Sustainable Food Production and Environment, eds T. Ando, K. Fujita, T. Mae, H. Matsumoto, S. Mori, and J. Sekiya (Dordrecht: Kluwer Academic Publishers), 891-895. doi: 10.1007/978-94-009-0047-9_287

Camejo, D., Jiménez, A., Alarcón, J. J., Torres, W., Gómez, J. M., and Sevilla, F. (2006). Changes in photosynthetic parameters and antioxidant activities following heat-shock treatment in tomato plants. Funct. Plant Biol. 33, 177-187. doi: 10.1071/FP05067

Camejo, D., Rodríguez, P., Morales, M. A., Dell'amico, J. M., Torrecillas, A., and Alarcón, J. J. (2005). High temperature effects on photosynthetic activity of two tomato cultivars with different heat susceptibility. J. Plant Physiol. 162, 281-289. doi: 10.1016/j.jplph.2004.07.014

Carpaneto, A., Geiger, D., Bamberg, E., Sauer, N., Fromm, J., and Hedrich, R. (2005). Phloem-localized, proton-coupled sucrose carrier ZmSUT1 mediates 
sucrose efflux under the control of the sucrose gradient and the proton motive force. J. Biol. Chem. 280, 21437-21443. doi: 10.1074/jbc.M501785200

Carrara, S., Pardossi, A., Soldatini, G. F., Tognoni, F., and Guidi, L. (2001). Photosynthetic activity of ripening tomato fruit. Photosynthetica 39, 75-78. doi: 10.1023/A:1012495903093

Carrari, F., Baxter, C., Usadel, B., Urbanczyk-Wochniak, E., Zanor, M. I., NunesNesi, A., et al. (2006). Integrated analysis of metabolite and transcript levels reveals the metabolic shifts that underlie tomato fruit development and highlight regulatory aspects of metabolic network behavior. Plant Physiol. 142, 1380-1396. doi: 10.1104/pp.106.088534

Centeno, D. C., Osorio, S., Nunes-Nesi, A., Bertolo, A. L., Carneiro, R. T., Araujo, W. L., et al. (2011). Malate plays a crucial role in starch metabolism, ripening, and soluble solid content of tomato fruit and affects postharvest softening. Plant Cell 23, 162-184. doi: 10.1105/tpc.109.072231

Chaves, M. M., Flexas, J., and Pinheiro, C. (2009). Photosynthesis under drought and salt stress: regulation mechanisms from whole plant to cell. Ann. Bot. 103 551-560. doi: 10.1093/aob/mcn 125

Chen, L.-Q., Qu, X.-Q., Hou, B.-H., Sosso, D., Osorio, S., Fernie, A. R., et al. (2012). Sucrose efflux mediated by SWEET proteins as a key step for phloem transport. Science 335, 207-211. doi: 10.1126/science.1213351

Chiou, T. J., and Bush, D. R. (1998). Sucrose is a signal molecule in assimilate partitioning. Proc. Natl. Acad. Sci. U.S.A. 95, 4784-4788. doi: 10.1073/pnas.95. 8.4784

Chourey, P. S., Taliercio, E. W., Carlson, S. J., and Ruan, Y.-L. (1998). Genetic evidence that the two isozymes of sucrose synthase present in developing maize endosperm are critical, one for cell wall integrity and the other for starch biosynthesis. Mol. Gen. Genet. 259, 88-96. doi: 10.1007/s004380050792

D'Aoust, M. A., Yelle, S., and Nguyen-Quoc, B. (1999). Antisense inhibition of tomato fruit sucrose synthase decreases fruit setting and the sucrose unloading capacity of young fruit. Plant Cell 11, 2407-2418. doi: 10.1105/tpc.11.12.2407

Dai, N., Schaffer, A., Petreikov, M., Shahak, Y., Giller, Y., Ratner, K., et al. (1999). Overexpression of Arabidopsis hexokinase in tomato plants inhibits growth, reduces photosynthesis, and induces rapid senescence. Plant Cell 11, 1253-1266. doi: 10.1105/tpc.11.7.1253

Damon, S., Hewitt, J., Nieder, M., and Bennet, A. B. (1998). Sink metabolism in tomato fruit. II. Phloem unloading and sugar uptake. Plant Physiol. 87, 731-736. doi: $10.1104 /$ pp.87.3.731

De Groot, C. C., Marcelis, L. F. M., Van den Boogaard, R., Kaiser, W. M., and Lambers, H. (2003). Interaction of nitrogen and phosphorus nutrition in determining growth. Plant Soil 248, 257-268. doi: 10.1023/A:1022323215010

De Groot, C. C., Marcelis, L. F. M., Van den Boogaard, R., and Lambers, H. (2001). Growth and dry-mass partitioning in tomato as affected by phosphorus nutrition and light. Plant Cell Environ. 24, 1309-1317. doi: 10.1046/j.00168025.2001.00788.x

Delucia, E. H., Sasek, T. W., and Strain, B. R. (1985). Photosynthetic inhibition after long-term exposure to elevated levels of atmospheric carbon dioxide. Photosyn. Res. 7, 175-184. doi: 10.1007/BF00037008

de Kroon, H., Huber, H., Stuefer, J. F., and van Groenendael, J. M. (2005) A modular concept of phenotypic plasticity in plants. New Phytol. 166, 73-82. doi: 10.1111/j.1469-8137.2004.01310.x

Dibley, S., Gear, M. L., Yang, X., Rosche, E. G., Offler, C. E., McCurdy, D. W., et al. (2005). Temporal and spatial expression of hexose transporters in developing tomato (Lycopersicon esculentum) fruit. Funct. Plant Biol. 32, 777-785. doi: 10.1071/FP04224

Do, P. T., Prudent, M., Sulpice, R., Causse, M., and Fernie, A. R. (2010). The influence of fruit load on the tomato pericarp metabolome in a Solanum chmielewskii introgression line population. Plant Physiol. 154, 1128-1142. doi: 10.1104/pp.110.163030

Endler, A., Meyer, S., Schelbert, S., Schneider, T., Weschke, W., Peters, S. W., et al. (2006). Identification of a vacuolar sucrose transporter in barley and Arabidopsis mesophyll cells by a tonoplast proteomic approach. Plant Physiol. 141, 196-207. doi: 10.1104/pp.106.079533

Evans, J. R., and Poorter, H. (2001). Photosynthetic acclimation of plants to growth irradiance: the relative importance of specific leaf area and nitrogen partitioning in maximizing carbon gain. Plant Cell Environ. 24, 755-767. doi: 10.1046/j.13653040.2001.00724.x

Farrar, J. F., and Williams, J. H. H. (1991). "Control of the rate of respiration in roots: compartmentation, demand and the supply of substrate," in Compartmentation of Plant Metabolism in Non-Photosynthetic Tissues, ed. M. Emes (Cambridge: Cambridge University Press), 167-188.

Frank, G., Pressman, E., Ophir, R., Althan, L., Shaked, R., Freedman, M., et al. (2009). Transcriptional profiling of maturing tomato (Solanum lycopersicum L.) microspores reveals the involvement of heat shock proteins, ROS scavengers, hormones, and sugars in the heat stress response. J. Exp. Bot. 60, 3891-3908. doi: 10.1093/jxb/erp234

Fridman, E., Carrari, F., Liu, Y. S., Fernie, A. R., and Zamir, D. (2004). Zooming in on a quantitative trait for tomato yield using interspecific introgressions. Science 305, 1786-1789. doi: 10.1126/science.1101666

Fridman, E., Liu, Y. S., Carmel-Goren, L., Gur, A., Shoresh, M., Pleban, T., et al. (2002). Two tightly linked QTLs modify tomato sugar content via different physiological pathways. Mol. Genet. Genomics 266, 821-826. doi: 10.1007/s00438-001-0599-4

Fujita, K., Okada, M., Lei, K., Ito, J., Ohkura, K., Adu-Gyamfi, J. J., et al. (2003). Effect of P-deficiency on photoassimilate partitioning and rhythmic changes in fruit and stem diameter of tomato (Lycopersicon esculentum) during fruit growth. J. Exp. Bot. 54, 2519-2528. doi: 10.1093/jxb/erg273

Garchery, C., Gest, N., Do, P. T., Alhagdow, M., Baldet, P., Menard, G., et al. (2013). A diminution in ascorbate oxidase activity affects carbon allocation and improves yield in tomato under water deficit. Plant Cell Environ. 36, 159-75. doi: 10.1111/j.1365-3040.2012.02564.x

Gary, C., Jones, J. W., and Longuenesse, J. J. (1993). Modelling daily changes of specific leaf area of tomato: the contribution of the leaf assimilate pool. Acta Hortic. 328, 205-210.

Gautier, H., Guichard, S., and Tchamitchian, M. (2001). Modulation of competition between fruits and leaves by flower pruning and water logging, and consequences on tomato leaf and fruit growth. Ann. Bot. 88, 645-652. doi: 10.1006/anbo.2001.1518

Gautier, H., Lopez-Lauri, F., Massot, C., Murshed, R., Marty, I., Grasselly, D., et al. (2010). Impact of ripening of salinity on tomato fruit ascorbate content and enzymatic activities related to ascorbate recycling. Funct. Plant Sci. Biotechnol. 4, $66-75$

Gautier, H., Massot, C., Stevens, R., Sérino, S., and Génard, M. (2009). Regulation of tomato fruit ascorbate content is more highly dependent on fruit irradiance than leaf irradiance. Ann. Bot. 103, 495-504. doi: 10.1093/aob/ $\operatorname{mcn} 233$

Génard, M., Bertin, N., Gautier, H., Lescourret, F., and Quilot, B. (2010). Virtual profiling: a new way to analyse phenotypes. Plant J. 62, 344-355. doi: 10.1111/j.1365-313X.2010.04152.x

Gómez, S., Ferrieri, R. A., Schueller, M., and Orians, C. M. (2010). Methyljasmonate elicits rapid changes in carbon and nitrogen dynamics in tomato. New Phytol. 188, 835-844. doi: 10.1111/j.1469-8137.2010.03414.x

Gómez, S., Steinbrenner, A. D., Osorio, S., Schueller, M., Ferrieri, R. A., Fernie, A. R., et al. (2012). From shoots to roots: transport and metabolic changes in tomato after simulated feeding by a specialist lepidopteran. Entomol. Exp. Appl. 144, 101-111. doi: 10.1111/j.1570-7458.2012.01268.x

Graf, A., Schlereth, A., Stitt, M., and Smith, A. M. (2010). Circadian control of carbohydrate availability for growth in Arabidopsis plants at night. Proc. Natl. Acad. Sci. U.S.A. 107, 9458-9463. doi: 10.1073/pnas.0914299107

Gur, A., and Zamir, D. (2004). Unused natural variation can lift yield barriers in plant breeding. PLoS Biol. 2:e245. doi: 10.1371/journal.pbio.00 20245

Guilioni, L., Wéry, J., and Tardieu, F. (1997). Heat stress-induced abortion of buds and flowers in pea. Is sensitivity linked to organ age or to relations between reproductive organs). Ann. Bot. 80, 159-168. doi: 10.1006/anbo.1997. 0425

Hackel, A., Schauer, N., Carrari, F., Fernie, A. R., Grimm, B., and Kuhn, C. (2006). Sucrose transporter LeSUT1 and LeSUT2 inhibition affects tomato fruit development in different ways. Plant J. 45, 180-192. doi: 10.1111/j.1365313X.2005.02572.x

Hädrich, N., Gibon, Y., Schudoma, C., Altmann, T., Lunn, J. E., and Stitt, M. (2011). Use of TILLING and robotised enzyme assays to generate an allelic series of Arabidopsis thaliana mutants with altered ADP-glucose pyrophosphorylase activity. J. Plant Physiol. 168, 1395-1405. doi: 10.1016/j.jplph.2011.01.013

Hare, P. D., Cress, W. A., and Van Staden, J. (1998). Dissecting the roles of osmolyte accumulation during stress. Plant Cell Environ. 21, 535-553. doi: 10.1046/j.13653040.1998.00309.x 
Havaux, M. (1993). Rapid photosynthetic adaptation to heat stress triggered in potato leaves by moderately elevated temperatures. Plant Cell Environ. 16, 461467. doi: 10.1111/j.1365-3040.1993.tb00893.x

Heyer, A. G., Raap, M., Schroeer, B., Marty, B., and Willmitzer, L. (2004). Cell wall invertase expression at the apical meristem alters floral, architectural, and reproductive traits in Arabidopsis thaliana. Plant J. 39, 161-169. doi: 10.1111/j.1365-313X.2004.02124.x

Hikosaka, K. (1996). Effects of leaf age, nitrogen nutrition and photon flux density on the organization of the photosynthetic apparatus in leaves of a vine (Ipomoea tricolor Cav.) grown horizontally to avoid mutual shading of leaves. Planta 198, 144-150. doi: 10.1007/BF00197597

Ho, L. C. (1996). The mechanism of assimilate partitioning and carbohydrate compartmentation in fruit in relation to the quality and yield of tomato. J. Exp. Bot. 47, 1239-1243. doi: 10.1093/jxb/47.Special_Issue.1239

Höfgen, R., Axelsen, K. B., Kannangara, C. G., Schüttke, I., Pohlenz, H. D., Willmitzer, L., et al. (1994). A visible marker for antisense mRNA expression in plants: inhibition of chlorophyll synthesis with a glutamate-1-semialdehyde aminotransferase antisense gene. Proc. Natl. Acad. Sci. U.S.A. 91, 1726-1730. doi: 10.1073/pnas.91.5.1726

Jang, J. C., and Sheen, J. (1994). Sugar sensing in higher plants. Plant Cell 6, 1665 1679. doi: 10.1105/tpc.6.11.1665

Jiménez, A., Creissen, G., Kular, B., Firmin, J., Robinson, S., and Mullineaux, P. (2002). Changes in oxidative processes and components of the antioxidant system during tomato fruit ripening. Planta 214, 751-758 doi: 10.1007/s0042501 00667

Jin, Y., Ni, D. A., and Ruan, Y. L. (2009). Posttranslational elevation of cell wall invertase activity by silencing its inhibitor in tomato delays leaf senescence and increases seed weight and fruit hexose level. Plant Cell 21, 2072-2089. doi: 10.1105/tpc.108.063719

Kahlau, S., and Bock, R. (2008). Plastid transcriptomics and translatomics of tomato fruit development and chloroplast-to-chromoplast differentiation: chromoplast gene expression largely serves the production of a single protein. Plant Cell 20, 856-874. doi: 10.1105/tpc.107.055202

Kaschuk, G., Hungria, M., Leffelaar, P. A., Giller, K. E., and Kuyper, T. W. (2010). Differences in photosynthetic behaviour and leaf senescence of soybean (Glycine $\max$ [L.] Merrill) dependent on $\mathrm{N}_{2}$ fixation or nitrate supply. Plant Biol. (Stuttg) 12, 60-69. doi: 10.1111/j.1438-8677.2009.00211.x

Klann, E. M., Hall, B., and Bennett, A. B. (1996). Antisense acid invertase (TIV1) gene alters soluble sugar composition and size in transgenic tomato fruit. Plant Physiol. 112, 1321-1330. doi: 10.1104/pp.112.3.1321

Kleessen, S., Antonio, C., Sulpice, R., Laitinen, R., Fernie, A. R., Stitt, M., et al. (2012). Structured patterns in geographic variability of metabolic phenotypes in Arabidopsis thaliana. Nat. Commun. 3:1319. doi: 10.1038/ncomms2333

Koch, K. (2004). Sucrose metabolism: regulatory mechanisms and pivotal roles in sugar sensing and plant development. Curr. Opin. Plant Biol. 7, 235-246. doi: 10.1016/j.pbi.2004.03.014

Koch, K. E. (1996). Carbohydrate-modulated gene expression in plants. Annu. Rev. Plant Physiol. Plant Mol. Biol. 47, 509-540. doi: 10.1146/annurev.arplant 47.1.509

Kolbe, A., Tiessen, A., Schluepmann, H., Paul, M., Ulrich, S., and Geigenberger, P. (2005). Trehalose 6-phosphate regulates starch synthesis via posttranslational redox activation of ADP-glucose pyrophosphorylase. Proc. Natl. Acad. Sci. U.S.A. 102, 11118-11123. doi: 10.1073/pnas.0503410102

Krapp, A., and Stitt, M. (1995). An evaluation of direct and indirect mechanisms for the 'sink-regulation' of photosynthesis in spinach: changes in gas exchange, carbohydrates, metabolites, enzyme activities and steady-state transcript levels after cold-girdling source leaves. Planta 195, 313-323. doi: 10.1007/ BF00202587

Kuhn, C., Hajirezaei, M. R., Fernie, A. R., Roessner-Tunali, U., Czechowski, T., Hirner, B., et al. (2003). The sucrose transporter StSUT1 localizes to sieve elements in potato tuber phloem and influences tuber physiology and development. Plant Physiol. 131, 102-113. doi: 10.1104/pp.011676

Lemaire-Chamley, M., Petit, J., Garcia, V., Just, D., Baldet, P., Germain, V., et al. (2005). Changes in transcriptional profiles are associated with early fruit tissue specialization in tomato. Plant Physiol. 139, 750-769. doi: 10.1104/pp.105. 063719

Li, Z., Palmer, W. M., Martin, A. P., Wang, R., Rainsford, F., Jin, Y., et al. (2012). High invertase activity in tomato reproductive organs correlates with enhanced sucrose import into, and heat tolerance of, young fruit. J. Exp. Bot. 63, 1155-1166. doi: $10.1093 /$ jxb/err329

Liu, Y. F., Qi, M. F., and Li, T. L. (2012). Photosynthesis, photoinhibition, and antioxidant system in tomato leaves stressed by low night temperature and their subsequent recovery. Plant Sci. 196, 8-17. doi: 10.1016/j.plantsci.2012. 07.005

Lytovchenko, A., Eickmeier, I., Pons, C., Osorio, S., Szecowka, M., Lehmberg, K., et al. (2011). Tomato fruit photosynthesis is seemingly unimportant in primary metabolism and ripening but plays a considerable role in seed development. Plant Physiol. 157, 1650-1663. doi: 10.1104/pp.111.186874

Lytovchenko, A., Sonnewald, U., and Fernie, A. R. (2007). The complex network of non-cellulosic carbohydrate metabolism. Curr. Opin. Plant Biol. 10, 227-235. doi: 10.1016/j.pbi.2007.04.002

MacRae, E., and Lunn, J. E. (2006). "Control of sucrose biosynthesis," in Advances in Plant Research, Vol. 22, Control of Primary Metabolism in Plants, eds W. C. Plaxton and M. T. McManus (Oxford: Blackwell), 234-257. doi: 10.1002/9780470988640.ch9

Makino, A., and Mae, T. (1999). Photosynthesis and plant growth at elevated levels of $\mathrm{CO}_{2}$. Plant Cell Physiol. 40, 999-1006. doi: 10.1093/oxfordjournals.pcp. a029493

Manaa, A., Ben Ahmed, H., Valot, B., Bouchet, J. P., Aschi-Smiti, S., Causse, M., et al. (2011). Salt and genotype impact on plant physiology and root proteome variations in tomato. J. Exp. Bot. 62, 2797-2813. doi: 10.1093/jxb/ erq460

Manaa, A., Faurobert, M., Valot, B., Bouchet, J. P., Grasselly, D., Causse, M., et al. (2013). Effect of salinity and calcium on tomato fruit proteome. OMICS 17, 338-352. doi: 10.1089/omi.2012.0108

McCurdy, D. W., Dibley, S., Cahyanegara, R., Martin, A., and Patrick, J. W. (2010). Functional characterization and RNAi-mediated suppression reveals roles for hexose transporters in sugar accumulation by tomato fruit. Mol. Plant 3, 10491063. doi: $10.1093 / \mathrm{mp} / \mathrm{ssq} 050$

McDowell, N.-G. (2011). Mechanisms linking frought, hydraulics, carbon metabolism, and vegetation mortality. Plant Physiol. 155, 1051-1059. doi: $10.1104 /$ pp.110.170704

McLaughlin, J. E., and Boyer, J. S. (2004). Sugar-responsive gene expression, invertase activity, and senescence in aborting maize ovaries at low water potentials. Ann. Bot. 94, 675-689. doi: 10.1093/aob/mch193

Mengel, K., and Kirkby, E. A. (1987). Principles of Plant Nutrition. Bern: International Potash Institute Worblaufen.

Menu, T., Saglio, P., Granot, D., Dai, N., Raymond, P., and Ricard, B. (2004). High hexokinase activity in tomato fruit perturbs carbon and energy metabolism and reduces fruit and seed size. Plant Cell Environ. 27, 89-98. doi: 10.1046/j.00168025.2003.01128.x

Metlen, K. L., Aschehoug, E. T., and Callaway, R. M. (2009). Plant behavioural ecology: dynamic plasticity in secondary metabolites. Plant Cell Environ. 32, 641-653 doi: 10.1111/j.1365-3040.2008.01910.x

Meyer, S., Lauterbach, C., Niedermeier, M., Barth, I., Sjolund, R. D., and Sauer, N. (2004). Wounding enhances expression of AtSUC3, a sucrose transporter from Arabidopsis sieve elements and sink tissues. Plant Physiol. 134, 684-693. doi: 10.1104/pp.103.033399

Micallef, B. J., Haskins, K. A., Wanderveer, P. J., Roh, K. S., Shewmaker, C. K., and Sharkey, T. D. (1995). Altered photosynthesis, flowering, and fruiting in transgenic tomato plants that have and increased capacity for sucrose synthesis. Planta 196, 327-334. doi: 10.1007/BF00201392

Miller, M. E., and Chourey, P. S. (1992). The maize invertase-deficient miniature-1 seed mutation is associated with aberrant pedicel and endosperm development. Plant Cell 4, 297-305. doi: 10.1105/tpc.4.3.297

Milner, I. D., Ho, L. C., and Hall, J. L. (1995). Properties of proton and sugar transport at the tonoplast of tomato (Lycopersicon esculentum) fruit. Physiol. Plant. 94, 399-410. doi: 10.1111/j.1399-3054.1995.tb00945.x

Moore, B. D., Cheng, S. H., Sims, D., and Seemann, J. R. (1999). The biochemical and molecular basis for photosynthetic acclimation to elevated atmospheric $\mathrm{CO}_{2}$. Plant Cell Environ. 22, 567-582. doi: 10.1046/j.1365-3040.1999. 00432.x

Muller, B., Pantin, F., Génard, M., Turc, O., Freixes, S., Piques, M., et al. (2011). Water deficits uncouple growth from photosynthesis, increase $\mathrm{C}$ content, and modify the relationships between $\mathrm{C}$ and growth in sink organs. J. Exp. Bot. 62, 1715-1729. doi: 10.1093/jxb/erq438 
Munns, R., Husain, S., Rivelli, A. R., James, R. A., Condon, A. G., Lindsay, M. P., et al. (2002). Avenues for increasing salt tolerance of crops, and the role of physiologically based selection traits. Plant Soil 247, 93-105. doi: 10.1023/A:1021119414799

Obiadalla-Ali, H., Fernie, A. R., Lytovchenko, A., Kossmann, J., and Lloyd, J. R. (2004). Inhibition of chloroplastic fructose 1,6-bisphosphatase in tomato fruits leads to decreased fruit size, but only small changes in carbohydrate metabolism. Planta 219, 533-540. doi: 10.1007/s00425-004-1257-y

Offler, C. E., and Horder, B. (1992). The cellular pathway of short distance transfer of photosynthates in developing tomato fruit. Plant Physiol. 99, 41.

Orians, C. M., Thorn, A., and Gómez, S. (2011). Herbivore-induced resource sequestration in plants: why bother? Oecologia 167, 1-9. doi: 10.1007/s00442011-1968-2

Osorio, S., Alba, R., Damasceno, C. M. B., Lopez-Casado, G., Lohse, M., Zanor, M. I., et al. (2011). Systems biology of tomato fruit development: combined transcript, protein and metabolite analysis of tomato transcription factor (nor, rin) and ethylene receptor $(\mathrm{Nr})$ mutants reveals novel regulatory interactions. Plant Physiol. 157, 405-425. doi: 10.1104/pp.111.175463

Osorio, S., Vallarino, J. G., Szecowka, M., Ufaz, S., Tzin, V., Angelovici, R., et al. (2013). Alteration of the interconversion of pyruvate and malate in the plastid or cytosol of ripening tomato fruit invokes diverse consequences on sugar but similar effects on cellular organic acid, metabolism, and transitory starch accumulation. Plant Physiol. 161, 628-643. doi: 10.1104/pp.112.211094

Patrick, J. W., and Offler, C. E. (1996). Post-sieve element transport of photoassimilates in sink regions. J. Exp. Bot. 47, 1165-1177. doi: 10.1093/jxb/47.Special_Issue.1165

Paul, M. J., and Driscoll, S. P. (1997). Sugar repression of photosynthesis: the role of carbohydrates in signalling nitrogen deficiency through source:sink imbalance. Plant Cell Environ. 20, 110-116. doi: 10.1046/j.1365-3040.1997.d01-17.x

Paul, M. J., and Foyer, C. H. (2001). Sink regulation of photosynthesis. J. Exp. Bot. 52, 1383-1400. doi: 10.1093/jexbot/52.360.1383

Paul, M. J., and Pellny, T. K. (2003). Carbon metabolite feedback regulation of leaf photosynthesis and development. J. Exp. Bot. 54, 539-547. doi: 10.1093/jxb/erg052

Pego, J. V., Kortsee, A. J., Huijser, C., and Smeekens, S. C. M. (2000). Photosynthesis, sugars and the regulation of gene expression. J. Exp. Bot. 51, 407-416. doi 10.1093/jexbot/51.suppl_1.407

Petreikov, M., Shen, S., Yeselson, Y., Levin, I., Bar, M., and Schaffer, A. A. (2006). Temporally extended gene expression of the ADP-Glc pyrophosphorylase large subunit (AgpL1) leads to increased enzyme activity in developing tomato fruit. Planta 224, 1465-1479. doi: 10.1007/s00425-006-0316-y

Petreikov, M., Yeselson, Y., Shen, S., Levin, I., Schaffer, A. A., Efrati, A., et al. (2009). Carbohydrate balance and accumulation during development of nearisogenic tomato lines differing in the AGPase-L1 allele. J. Am. Soc. Hortic. Sci. 134, 134-140.

Poljakoff-Mayber, A., and Lerner, H. (1994). "Plants in saline environments," in Handbook of Plant and Crop Stress, ed. M. Pessarakli (New York: Marcel Dekker), 65-96.

Pressman, E., Harel, D., Zamski, E., Shaked, R., Althan, L., Rosenfeld, K., et al. (2006). The effect of high temperatures on the expression and activity of sucrosecleaving enzymes during tomato (Lycopersicon esculentum) anther development. J. Hortic. Sci. Biotechnol. 81, 341-348.

Pressman, E., Peet, M. M., and Pharr, D. M. (2002). The effect of heat stress on tomato pollen characteristics is associated with changes in carbohydrate concentration in developing anthers. Ann. Bot. 90, 631-636. doi: 10.1093/aob/mcf240

Prudent, M., Lecomte, A., Bouchet, J. P., Bertin, N., Causse, M., and Genard M. (2011). Combining ecophysiological modelling and quantitative trait locus analysis to identify key elementary processes underlying tomato fruit sugar concentration. J. Exp. Bot. 62, 907-919. doi: 10.1093/jxb/erq318

Pyl, E. T., Piques, M., Ivakov, A., Schulze, W., Ishihara, H., Stitt, M., et al. (2012). Metabolism and growth in Arabidopsis depend on the daytime temperature but are temperature-compensated against cool nights. Plant Cell 24, 2443-2469. doi: 10.1105/tpc. 112.097188

Reinders, A., Schulze, W., Kuhn, C., Barker, L., Schulz, A., Ward, J. M., et al. (2002). Protein-protein interactions between sucrose transporters of different affinities colocalized in the same enucleate sieve element. Plant Cell 14, 1567-1577. doi: $10.1105 /$ tpc. 002428
Riesmeier, J. W., Hirner, B., and Frommer, W. B. (1993). Potato sucrose transporter expression in minor veins indicates a role in phloem loading. Plant Cell 5, 15911598. doi: 10.1105/tpc.5.11.1591

Riesmeier, J. W., Willmitzer, L., and Frommer, W. B. (1994). Evidence for an essential role of the sucrose transporter in phloem loading and assimilate partitioning. EMBO J. 13, 1-7.

Roitsch, T., and Gonzalez, M. C. (2004). Function and regulation of plant invertases: sweet sensations. Trends Plant Sci. 9, 606-613. doi: 10.1016/j.tplants.2004.10.009

Romero-Aranda, R., Soria, T., and Cuartero, J. (2001). Tomato plant-water uptake and plant-water relationships under saline growth conditions. Plant Sci. 160, 265-272. doi: 10.1016/S0168-9452(00)00388-5

Ruan, Y., and Patrick, J. (1995). The cellular pathway of post phloem sugar transport in developing tomato fruit. Planta 196, 434-444. doi: 10.1007/BF00203641

Ruan, Y., Patrick, J., and Brady, C. (1997). Protoplast hexose carrier activity is a determinate of genotypic difference in hexose storage in tomato fruit. Plant Cell Environ. 20, 341-349. doi: 10.1046/j.1365-3040.1997.d01-73.x

Ruan, Y. L., Jin, Y., Yang, Y. J., Li, G. J., and Boyer, J. S. (2010). Sugar input, metabolism, and signaling mediated by invertase: roles in development, yield potential, and response to drought and heat. Mol. Plant 3, 942-955. doi: $10.1093 / \mathrm{mp} / \mathrm{ssq} 044$

Ruan, Y. L., Llewellyn, D. J., Liu, Q., Xu, S. M., Wu, L. M., Wang, L., et al. (2008). Expression of sucrose synthase in the developing endosperm is essential for early seed development in cotton. Funct. Plant Biol. 35, 382-393. doi: 10.1071/FP08017

Ruan, Y. L., Patrick, J. W., Bouzayen, M., Osorio, S., and Fernie, A. R. (2012). Molecular regulation of seed and fruit set. Trends Plant Sci. 17, 656-665. doi: 10.1016/j.tplants.2012.06.005

Sage, R. F., Sharkey, T. D., and Seemann, J. R. (1989). Acclimation of photosynthesis to elevated $\mathrm{CO}_{2}$ in five C3 species. Plant Physiol. 89, 590-596. doi: 10.1104/pp.89.2.590

Sala, A., Woodruff, D. R., and Meinzer, F. C. (2012). Carbon dynamics in trees: feast or famine? Tree Phyol. 32, 764-775. doi: 10.1093/treephys/tpr143

Sato, S., Peet, M. M., and Thomas, J. F. (2000). Physiological factors limit fruit set of tomato (Lycopersicon esculentum Mill.) under chronic, mild heat stress. Plant Cell Environ. 23, 719-726. doi: 10.1046/j.1365-3040.2000.00589.x

Sauer, N., Ludwig, A., Knoblauch, A., Rothe, P., Gahrtz, M., and Klebl, F. (2004). AtSUC8 and AtSUC9 encode functional sucrose transporters, but the closely related AtSUC6 and AtSUC7 genes encode aberrant proteins in different Arabidopsis ecotypes. Plant J. 40, 120-130. doi: 10.1111/j.1365-313X.2004. 02196.x

Schaffer, A. A., and Petreikov, M. (1997). Sucrose-to-starch metabolism in tomato fruit undergoing transient starch accumulation. Plant Physiol. 113, 739-746.

Schauer, N., Semel, Y., Roessner, U., Gur, A., Balbo, I., Carrari, F., et al. (2006). Comprehensive metabolic profiling and phenotyping of interspecific introgression lines for tomato improvement. Nat. Biotechnol. 24, 447-454. doi: $10.1038 / \mathrm{nbt} 1192$

Schwachtje, J., Minchin, P. E. H., Jahnke, S., van Dongen, J. T., Schittko, U., and Baldwin, I. T. (2006). SNF1-related kinases allow plants to tolerate herbivory by allocating carbon to roots. Proc. Natl. Acad. Sci. U.S.A. 103, 12935-12940. doi: 10.1073/pnas.0602316103

Smeekens, S., Ma, J. K., Hanson, J., and Rolland, F. (2010). Sugar signals and molecular networks controlling plant growth. Curr. Opin. Plant 13, 274-279. doi: 10.1016/j.pbi.2009.12.002

Smith, A. M., and Stitt, M. (2007). Coordination of carbon supply and plant growth. Plant Cell Environ. 30, 1126-1149. doi: 10.1111/j.1365-3040.2007.01708.x

Steinbrenner, A. D., Gómez, S., Osorio, S., Fernie, A. R., and Orians, C. M. (2011). Herbivore-induced changes in tomato (Solanum lycopersicum) primary metabolism: a whole plant perspective. J. Chem. Ecol. 37, 1294-1303. doi: 10.1007/s10886-011-0042-1

Steinhauser, M. C., Steinhauser, D., Koehl, K., Carrari, F., Gibon, Y., Fernie, A. R., et al. (2010). Enzyme activity profiles during fruit development in tomato cultivars and Solanum pennellii. Plant Physiol. 153, 80-98. doi: $10.1104 / \mathrm{pp} .110 .154336$

Stitt, M. (1991). Rising $\mathrm{CO}_{2}$ levels and their potential significance for carbon flow in photosynthetic cells. Plant Cell Environ. 14, 741-762. doi: 10.1111/j.13653040.1991.tb01440.x

Stitt, M., Lunn, J., and Usadel, B. (2010). Arabidopsis and primary photosynthetic metabolism: more than the icing on the cake. Plant J. 6, 1067-1091. doi: 10.1111/j.1365-313X.2010.04142.x 
Stitt, M., and Zeeman, S. C. (2012). Starch turnover: pathways, regulation and role in growth. Curr. Opin. Plant Biol. 15, 282-292. doi: 10.1016/j.pbi.2012. 03.016

Sulpice, R., Flis, A., Ivakov, A. A., Apelt, F., Krohn, N., Encke, B., et al. (2014). Arabidopsis coordinates the diurnal regulation of carbon allocation and growth across a wide range of photoperiods. Mol. Plant 7, 137-155. doi: 10.1093/mp/ sst127

Sulpice, R., Nikoloski, Z., Tschoep, H., Antonio, C., Kleessen, S., Larhlimi, A., et al. (2013). Impact of the carbon and nitrogen supply on relationships and connectivity between metabolism and biomass in a broad panel of Arabidopsis accessions. Plant Physiol. 162, 347-363. doi: 10.1104/pp.112.210104

Sulpice, R., Pyl, E. T., Ishihara, H., Trenkamp, S., Steinfath, M., WituckaWall, H., et al. (2009). Starch as a major integrator in the regulation of plant growth. Proc. Natl. Acad. Sci. U.S.A. 106, 10348-10353. doi: 10.1073/pnas.09034 78106

Sultan, S. E. (2000). Phenotypic plasticity for plant development, function and life history. Trends Plant Sci. 17, 278-285.

Tanaka, A., Fujita, K., and Kikuchi, K. (1974). Nutrio-physiological studies on the tomato plant. III. Photosynthetic rate on individual leaves in relation to dry matter production of plants. Soil Sci. Plant Nutr. 20, 173-183. doi: 10.1080/00380768.1974.10433240

Tiessen, A., and Padilla-Chacon, D. (2013). Subcellular compartmentation of sugar signaling: links among carbon cellular status, route of sucrolysis, sinksource allocation, and metabolic partitioning. Front. Plant Sci. 3:306. doi: 10.3389/fpls.2012.00306

Toubiana, D., Semel, Y., Tohge, T., Beleggia, R., Cattivelli, L., Rosental, L., et al. (2012). Metabolic profiling of a mapping population exposes new insights in the regulation of seed metabolism and seed, fruit, and plant relations. PLoS Genet. 8:e1002612. doi: 10.1371/journal.pgen.1002612

Valentin, N., Gary, C., Vaissiere, B. E., Tchamitchian, M., and Bruneli, B. (1998). Changing sink demand affects the area but not the specific activity of assimilate sources in cantaloupe (Cucumis melo L.). Ann. Bot. 82, 711-719. doi: 10.1006/anbo.1998.0739

Van Oosten, J. J., and Besford, R. T. (1995). Some relationships between the gas exchange, biochemistry and molecular biology of photosynthesis during leaf development of tomato plants after transfer to different carbon dioxide concentrations. Plant Cell Environ. 18, 1253-1266. doi: 10.1111/j.13653040.1995.tb00185.x

Van Oosten, J. J., Wilkins, S., and Besford, R. T. (1994). Regulation of the expression of photosynthetic nuclear genes by high $\mathrm{CO}_{2}$ is mimicked by carbohydrates: a mechanism for the acclimation of photosynthesis to high $\mathrm{CO}_{2}$. Plant Cell Environ. 17, 913-923. doi: 10.1111/j.1365-3040.1994.tb00320.x

Viola, R., Roberts, A. G., Haupt, S., Gazzani, S., Hancock, R. D., Marmiroli, N., et al. (2001). Tuberization in potato involves a switch from apoplasmic to symplasmic phloem unloading. Plant Cell 13, 385-398. doi: 10.1105/tpc.13.2.385
Vu, J. C. V., Gesch, R. W., Allen, L. H., Boote, K. J., and Bowes, G. (1999). CO 2 enrichment delays a rapid, drought induced decrease in Rubisco small subunit transcript abundance. J. Plant Physiol. 155, 139-142. doi: 10.1016/S0176-1617(99) 80156-4

Wang, H., Schauer, N., Usadel, B., Frasse, P., Zouine, M., Hernould, M., et al. (2009). Regulatory features underlying pollination-dependent and -independent tomato fruit set revealed by transcript and primary metabolite profiling. Plant Cell 21, 1428-1452. doi: 10.1105/tpc.108.060830

Weaver, M. L., and Timm, H. (1989). Screening tomato for high temperature tolerance through pollen viability tests. HortScience 24, 493-495.

Weise, A., Barker, L., Kuhn, C., Lalonde, S., Buschmann, H., Frommer, W. B., et al. (2000). A new subfamily of sucrose transporters, SUT4, with low affinity/high capacity localized in enucleate sieve elements of plants. Plant Cell 12, 1345-1355. doi: $10.1105 /$ tpc.12.8.1345

Zanor, M. I., Osorio, S., Nunes-Nesi, A., Carrari, F., Lohse, M., Usadel, B., et al. (2009). RNA interference of LIN5 in tomato confirms its role in controlling Brix content, uncovers the influence of sugars on the levels of fruit hormones, and demonstrates the importance of sucrose cleavage for normal fruit development and fertility. Plant Physiol. 150, 1204-1218. doi: 10.1104/pp.109.136598

Zhang, C. K., and Turgeon, R. (2009). Downregulating the sucrose transporter VpSUT1 in Verbascum phoeniceum does not inhibit phloem loading. Proc. Natl. Acad. Sci. U.S.A. 106, 18849-18854. doi: 10.1073/pnas.0904189106

Zhang, H. X., and Blumwald, E. (2001). Transgenic salt-tolerant tomato plants accumulate salt in foliage but not in fruit. Nat. Biotechnol. 19, 765-768. doi: $10.1038 / 90824$

Zrenner, R., Schuler, K., and Sonnewald, U. (1996). Soluble acid invertase determines the hexose-to-sucrose ratio in cold-stored potato tubers. Planta 198, 246-252. doi: 10.1007/BF00206250

Conflict of Interest Statement: The authors declare that the research was conducted in the absence of any commercial or financial relationships that could be construed as a potential conflict of interest.

Received: 14 June 2013; accepted: 14 September 2014; published online: 06 October 2014.

Citation: Osorio S, Ruan Y-L and Fernie AR (2014) An update on source-to-sink carbon partitioning in tomato. Front. Plant Sci. 5:516. doi: 10.3389/fpls.2014.00516 This article was submitted to Functional Plant Ecology, a section of the journal Frontiers in Plant Science.

Copyright (C) 2014 Osorio, Ruan and Fernie. This is an open-access article distributed under the terms of the Creative Commons Attribution License (CC BY). The use, distribution or reproduction in other forums is permitted, provided the original author(s) or licensor are credited and that the original publication in this journal is cited, in accordance with accepted academic practice. No use, distribution or reproduction is permitted which does not comply with these terms. 